\title{
Miranda
}

Revue pluridisciplinaire du monde anglophone /

Multidisciplinary peer-reviewed journal on the English-

speaking world

$4 \mid 2011$

Samuel Beckett : Drama as philosophical endgame?

\section{Katherine Byrne, Tuberculosis and the Victorian \\ Literary Imagination}

Laurence Talairach-Vielmas

\section{OpenEdition}

\section{Journals}

\section{Electronic version}

URL: http://journals.openedition.org/miranda/5085

DOI: 10.4000/miranda.5085

ISSN: 2108-6559

Publisher

Université Toulouse - Jean Jaurès

\section{Electronic reference}

Laurence Talairach-Vielmas, "Katherine Byrne, Tuberculosis and the Victorian Literary Imagination",

Miranda [Online], 4 | 2011, Online since 24 June 2011, connection on 16 February 2021. URL: http:// journals.openedition.org/miranda/5085 ; DOI: https://doi.org/10.4000/miranda.5085

This text was automatically generated on 16 February 2021.

\section{cc) (i) () $\Theta$}

Miranda is licensed under a Creative Commons Attribution-NonCommercial-NoDerivatives 4.0 International License. 


\title{
Katherine Byrne, Tuberculosis and the Victorian Literary Imagination
}

\author{
Laurence Talairach-Vielmas
}

\section{REFERENCES}

Katherine Byrne, Tuberculosis and the Victorian Literary Imagination (Cambridge:

Cambridge University Press, 2011), 223 p, ISBN 978-0-521-76667-8

Why was the Victorian feminine ideal emaciated and consumptive, epitomized by Dante Gabriel Rossetti's wife, Elizabeth Siddal, aestheticized as she was dying in Beata Beatrix? This is one of the questions that Katherine Byrne's Tuberculosis and the Victorian Literary Imagination addresses, explaining how pulmonary tuberculosis, or phtisis, a disease which was at its height in Europe in the nineteenth century influenced "the construction of the nineteenth-century social body through its pathologising of the gender, class, and economic and aesthetic status of the individual body" (1). Consumption not only killed more people than cholera and smallpox combined, but it was also mysterious as the symptoms associated with consumption were manifold, and the disease was likely to affect indifferently the brain, skin, lungs or stomach. Interestingly, as Byrne highlights, the disease enabled Victorian writers to create textual tropes, whether in relation to purity or sexuality. Through studies of Victorian novels (or American works of the same period written and set in England, such as Henry James's Portrait of a Lady [1881]), as well as British paintings, Byrne looks at representations of consumption in both Victorian medical writing and cultural representations.

Chapter 1 focuses on nineteenth-century medical discourse on tuberculosis and the percentage of the population affected by the disease. Its intention is to understand not only its social significance, but also its cultural significance, particularly manifest in its appearance in the social problem novel of the 1840s and 1850s. As Byrne makes explicit, physicians used cultural representations of the disease in their medical writings, 
helping to purvey cultural stereotypes and associations of consumption with enduring myths. As she argues, this helped link the disease with ways of life, revealing the role of doctors in controlling their patients both morally and physically (from food restriction -ironically enough since consumptives hardly ate-to physical cleanliness). The way in which medical practitioners emphasized the social construction of consumption was reflected in Victorian novels, which very often played with some of the contradictions inherent in medical texts. The consumptive characters, either embodying saintly spirituality or sexual depravation, were in most cases female characters, phtisis being defined as a female disease while figures do not necessarily provide evidence of this. Still, the links between uterine disorders as pre-disposing causes of pulmonary disorders or the connections between the menstrual period and pulmonary haemorrhage, show that consumption was closely connected with the female reproductive system. It is hard to see the point Byrne tries to make, however, through her choice of novels which were published at very different times, Mrs Henry Wood's East Lynne (1861-and not 1900 as argued), Mrs Ward's Eleanor (1900) or Emily Brontë's Wuthering Heights (1847), or whether she attempts to trace an evolution in the figure of the consumptive (and in this case the non-chronological order in which the works are analysed is confusing).

Chapter 2 deals with representations of consumption in Condition of England novels. Byrne looks at Charles Dickens's Dombey and Son (1846-48) and Elizabeth Gaskell's North and South (1854-55) and underlines the role disease played in the novels written or set in the "hungry forties". Consumption might seem to result from deprivation, but was also a disease linked to the higher classes' excess. In both cases, it was politicised in order to reflect the ills of capitalism: Dickens's denunciation of consumer society in Dombey and Son hinges upon his representation of the consumptive heir of the family. Dickens plays upon the ability of tuberculosis to disrupt the industrial world: Paul Dombey's angelic nature is brought out by the disease-a pathological force produced by capitalism. In North and South, on the other hand, phtisis is caused by the lower classes' working conditions (poorly ventilated factories) and is simultaneously associated with the consumption of luxury goods. Standing for capitalist exploitation or over-consumption, used as a trope for luxury and deprivation, Victorian novelists thus capitalized on the polyvalent meanings of tuberculosis, most especially in social problem novels, since the disease could serve as a "powerful leveller of class" (68).

In Chapter 3, Byrne analyses the figure of the consumptive in Mrs Ward's Eleanor (1900), a novel she briefly compares to Henry James's Wings of the Dove (1902), which also sets a female invalid against an Italian backdrop. The parallel between Ward's heroine's journey through Italy and the disease's progression within her body enables Ward to use consumption to reflect her heroine's mental state, thus connecting mind and body to represent emotional unhappiness. Comparing Eleanor with Charlotte Brontë's Caroline Helstone in Shirley (1849), Byrne explains the links or confusions between consumption and anorexia nervosa as both diseases highlighted a denial of bodily appetites and needs.

Byrne then turns to artistic representations of the consumptive woman, drawing on Bram Djikstra's Idols of Perversity, and situates consumption within the cult of invalidism. As she argues, the female invalid epitomized capitalism: unproductive, draining the household finances, the female invalid reflected her husband's economic power. Byrne looks at Dante Gabriel Rossetti's aestheticisation of phtisis through his 
representations of Elizabeth Siddal. Rossetti, Byrne contends, as well as Siddal, probably "manipulated and exploited the transforming power of the consumptive aesthetic for social and economic ends" (96). She then compares Siddal to George Du Maurier's eponymous Trilby, both women showing the close relations between the cult of invalidism and the cult of the dead woman. Mentioning Charles Reade's A Simpleton (1886), Byrne also recalls how the wearing of corsetry caused consumption and was denounced by the medical profession, medical practitioners raising young women's awareness on the need to avoid pathological lifestyles.

Chapter 5, on Bram Stoker's Dracula (1897), highlights the relationship between consumption and vampirism. Like other diseases, such as anaemia, cholera or porphyria, vampirism has often been associated with different wasting diseases. However, Byrne shows that Victorian literary vampires exhibit symptoms traditionally linked to consumption, a link that could even be found in real life since victims of tuberculosis were sometimes exhumed to exorcise fears of vampirism. Bram Stoker was not only Rossetti's neighbour and probably influenced by his opening of Siddal's coffin seven years after her death to exhume his buried poems (and the discovery of her stillperfect corpse) but he was also known to keep newspaper clippings mentioning cases of death by consumption believed to be cases of vampirism. This may explain why in Dracula the description of Lucy's death is caught within a pathological discourse more than a supernatural one. Byrne sets parallels with Le Fanu's Carmilla, even drawing on Thomas Beddoes's 1799 Essay on the Causes Early Signs of, and Prevention of Pulmonary Consumption and the physician's description of the consumptive, to bring to light the echo between nineteenth-century medical literature and Victorian literary vampires. The link between these consumptive women and the supernatural figure of the vampire points out the disease's power to act as a metaphor for mystery and the supernatural through its shifty appearance and meanings.

7 Chapter 6 deals with Henry James's The Portrait of a Lady and shifts the focus to the depiction of the male consumptive. Ralph Touchett, probably inspired by Minny Temple, James's younger cousin who died of phtisis, is an effeminate and self-sacrificial figure. Though consumption is in no way a means of aestheticizing him, his sickly body nonetheless brings out his pure soul, James thus capitalizing on the construction of consumption as a "spiritualising disease" (172). Because he is not the main character of the novel, Ralph sheds light on the role played by consumptive characters in canonical Victorian novels, such as Helen Burns in Jane Eyre (1847), serving as foils to the main characters and reflecting "the better half of the central character" (171).

However, when Robert Koch identified the bacteria at the root of consumption in 1882, tuberculosis lost part of its symbolical power. There was very little mystery left in the bacterial infection which had yet endowed with so much beauty the ethereal wasting women of Victorian art and literature. In the twentieth century, tuberculosis became instead a symbol of war and a consequence of it, novels playing on the image of the sanatorium in twentieth-century "tubercular" novels. If the first and second World Wars revisited the literary consumptive, the male body replacing the female body and becoming an object of medical concern, invalidism was nevertheless not shown as natural, but as resulting, on the contrary, from a pathological society. In the 1950s, the widespread use of streptomycin put an end to the metaphorical power of the disease, leaving the stage free for diseases that still baffled the medical profession: it was time 
for consumption to swap place with leukaemia and for images of aesthetic illnesses to be revamped.

Byrne's tracing of the trajectory of a particular disease and its various symbolical meanings enables the reader to make his way through literary and medical writings of the nineteenth century. Even if the grouping of texts may sometimes confuse the reader, Tuberculosis and the Victorian Literary Imagination is a convincing study of tuberculosis, a disease which is recurrently shrouded in mystery in Victorian novels. More significantly still, Byrne's study underlines the metaphorical power of disease and its cultural impact and will undoubtedly appeal to students and scholars interested in nineteenth-century constructions of the body and in interdisciplinary research.

INDEX

Keywords: Victorian novel, Victorian art, tuberculosis, medicine

Mots-clés: roman victorien, art victorien, tuberculose, médecine

\section{AUTHORS}

\section{LAURENCE TALAIRACH-VIELMAS}

Professeur

Université Toulouse 2 - Le Mirail

talairac@univ-tlse2.fr 